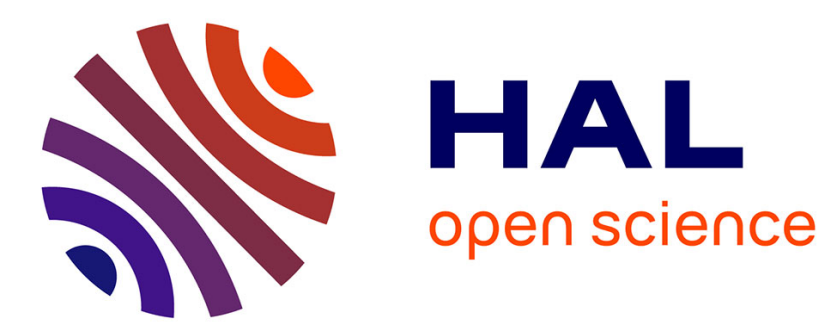

\title{
Stature Estimation from Hand and Foot Dimensions Reveals a Similar Allometric Relationship in Sudanese Arabs and Somalis
}

Fernando V Ramirez Rozzi, D Gassimalla, N Abdalazeem, F Elamin

\section{- To cite this version:}

Fernando V Ramirez Rozzi, D Gassimalla, N Abdalazeem, F Elamin. Stature Estimation from Hand and Foot Dimensions Reveals a Similar Allometric Relationship in Sudanese Arabs and Somalis. Bulletins et Mémoires de la Société d'anthropologie de Paris, 2020, 32 (3-4), pp.168 - 177. 10.3166/bmsap2020-0093 . hal-03356208

\section{HAL Id: hal-03356208 \\ https://hal.science/hal-03356208}

Submitted on 29 Sep 2021

HAL is a multi-disciplinary open access archive for the deposit and dissemination of scientific research documents, whether they are published or not. The documents may come from teaching and research institutions in France or abroad, or from public or private research centers.
L'archive ouverte pluridisciplinaire HAL, est destinée au dépôt et à la diffusion de documents scientifiques de niveau recherche, publiés ou non, émanant des établissements d'enseignement et de recherche français ou étrangers, des laboratoires publics ou privés. 


\title{
Stature Estimation from Hand and Foot Dimensions Reveals a Similar Allometric Relationship in Sudanese Arabs and Somalis
}

\author{
L'estimation de la stature à partir des dimensions du pied et de la main met en évidence \\ une même relation allométrique chez les Soudanais arabes et les Somalis
}

\author{
F.V. Ramirez Rozzi · D. Gassimalla $\cdot$ N. Abdalazeem · F. Elamin
}

\begin{abstract}
Population-specific anthropometric standards serve as a guide to forensic practitioners for identification purposes. However, few studies have observed on whether the relationship between stature and body parts differs among populations. Our aim is to first assess the validity of using hand and foot dimensions to estimate stature in two geographically similar but linguistically different populations, Sudanese Arabs and Somalis, and then secondly to assess whether the relationship between hand and foot dimensions and stature differ among these populations. Standard anthropometric measurements were used to assess sexual dimorphism. Regressions were performed to establish the relationship between body parts and stature and were compared among the populations to describe the allometry. Comparisons between regression coefficients reveal that 1) stature has the same relationship with hand and foot lengths in each population and 2) the relationship between stature/ hand length and foot length is the same (isometric) in both populations. These results suggest a close affinity between the two groups. Hand and foot length can be used to estimate the stature of individuals but not to identify sex or differentiate one population from the other.
\end{abstract}

\section{F.V. Ramirez Rozzi $(\bowtie)$}

UMR 7206 Écoanthropologie, CNRS-MNHN,

musée de l'Homme, 17, place du Trocadéro,

F-75116 Paris, France

e-mail : fernando.ramirez-rozzi@mnhn.fr

D. Gassimalla $\cdot$ N. Abdalazeem · F. Elamin $(\bowtie)$

Khartoum Centre for Research and Medical Training,

Qasr Street, Khartoum, Sudan

e-mail : fadilelamin@yahoo.co.uk

\section{F. Elamin}

Queen Mary University of London, Institute of Dentistry, Bart's and The London School of Medicine and Dentistry, London, E1 2AT, United Kingdom

El-Razi Dental School, Elazhari 2, Khartoum, Sudan
Keywords Stature estimation · Sudanese Arabs · Somalis · Allometry

Résumé Des référentiels anthropométriques servent aux médecins légistes à établir le profil biologique des individus. Cependant peu d'études ont observé si la relation entre la stature et les dimensions des parties du corps sont différentes entre les populations. Cette étude évalue en premier lieu la validité de l'utilisation des dimensions des mains et des pieds pour estimer la stature de deux populations géographiquement similaires mais linguistiquement différentes, les Arabes soudanais et les Somaliens. Elle évalue ensuite si le même rapport est présent dans les deux populations. Des mesures anthropométriques standard ont été utilisées pour évaluer le dimorphisme sexuel. Des régressions ont été effectuées pour établir la relation entre les dimensions des parties du corps avec la stature et ont été comparées entre les populations pour décrire les processus allométriques. La comparaison des coefficients de régression révèle que : 1) la stature entretient la même relation avec les longueurs des mains et des pieds dans les deux populations ; 2) la relation entre le ratio stature/longueur des mains et la longueur des pieds est la même (isométrique) entre les populations. Ces résultats suggèrent une affinité étroite entre ces groupes. La longueur des mains et des pieds peut être utilisée dans l'estimation de la stature des individus, mais ne permet pas l'identification du sexe et la distinction entre les populations.

Mots clés Estimation de la stature $\cdot$ Soudanaises arabes Somalies $\cdot$ Allométrie

\section{Introduction}

The relationship between stature and the size of body parts is an important factor for identification purposes. Mutilated bodies from catastrophes and terror attacks may have to be 
identified from a single body part. Forensic practice requires an accurate biological profile of victims to be established. Ancestry, sex, age and stature are the "Big Four" of identification in forensic anthropometry.

Adult stature results from complex interactions between genetic, epigenetic and environmental factors. Average adult stature differs between human populations [e.g. 1-5]. The differences in stature and the size of body parts of populations living in distinct latitude and climatic conditions show the influence of environmental factors $[3,6]$. This environmental conditioning can also be observed in populations with a similar phenotype, such as Pygmy populations from East and West Africa where the phenotype is acquired by a distinctive process and reveals convergent evolution [7]. On the other hand, populations living in similar environments exhibit different average adult statures. This is reported among Pygmies and Bantu-speaking neighbours [e.g. 8,9] and suggests a genetic difference [10].

As stature and body proportions vary between populations, the mathematical formulae predicting stature from body part sizes need to be population-specific. Identifying human remains using regression equations from different populations can cause misidentification. In other words, estimations made by extrapolating from the equation for a different population will affect forensic diagnosis and identification.

Anthropometric data suggest highly correlated relationships between stature and different anatomical parts in populations around the world. It is still unclear that whether this relationship is similar among different populations. From the perspective of forensic medicine, establishing the accuracy of regression equations is important. In anthropology, different relationships between stature and body parts could be attributed to changes in scaling, suggesting allometric differences between populations. Changes in scaling can be associated with particular environmental adaptations as suggested by Bergmann's and Allen's rules for our broadly distributed species [11].

Anthropometry has been established for Europeans and other populations in the world, but is notably lacking for populations in regions of armed conflict, and Sudan is no exception. The only body of work from this region is by Ahmed and his colleagues [12-15] who have published many regression equations to estimate stature from craniocephalic, lower limb and upper limb measurements of Sudanese Arabs. The majority of cranio-cephalic dimensions and all upper and lower limb measurements show correlations with stature. The coefficient of determination is very low for cranio-cephalic dimensions and the highest values correspond to tibia and foot length (no other lengths have been obtained for lower members). Based on correlation coefficients and coefficients of determination, Ahmed [12] suggests that some dimensions are more reliable than others to estimate stature. However, no tests have been performed to validate this suggestion. Ahmed and his colleagues have contributed to the knowledge on Sudanese morphology but no regional studies exist for comparison.

The aim of this study was to assess the relationship between stature and anthropometric measurements of hands and feet in two East African groups-Sudanese Arabs and Somalis. Correlations among traits were established for each population and linear regression formulae were constructed to assess the estimation of stature from the measurements of hands and feet. The populations were compared to establish any similarity between stature and hand or foot lengths between populations. The allometry was analyzed to compare scaling effects.

\section{Material and Methods}

The subjects recruited for the study were healthy adult Sudanese Arab and Somali volunteers (over 18 years of age) living in Khartoum, Sudan. The study was conducted in a dental referral clinic in Khartoum between September and November 2017. Prior informed consent was obtained from each individual participating in the study. Permission for the research was obtained from the Ethical Committee Board of the Khartoum Centre for Research and Medical Training in accordance with the guidelines of the Federal Ministry of Health of Sudan. We are aware that the sample size, especially for Somali people, is low for forensic medicine standards, but access to a Somali population is very limited. Both countries suffer from political instability, with a relatively small Somali student diaspora and migrants. To avoid comparing two populations with a different sample size, the number of Sudanese Arabs included in the study was made close to that of Somalis. Stature, weight and hand and foot lengths and widths were measured once by the same observer (N.A.) in 99 Sudanese Arabs (Female = 49 , Male $=50)$ and 69 Somalis $($ Female $=28$, Male $=41)$. We are aware that intra and inter-observer tests are needed for the method to be valid and that without these tests, measurements become observer-dependent. Our study therefore presents this limitation, which is the same as in almost all previous studies on Sudanese and other non-European populations [e.g. 12-15], since these avoid inter-observer variation (measurements taken only by one observer) and no intra-observer test is carried out. Furthermore, studies based on anthropometric measurements are extremely limited for these two populations, because of the historical reasons and the current political and social situation, hence, few data are available on Sudanese Arabs and even fewer on Somalis. Weights were measured with an electronic scale to the nearest $0.1 \mathrm{~kg}$, height with a steel height gauge to the nearest $0.1 \mathrm{~cm}$ and hand and foot length with digital 
sliding callipers to the nearest $0.1 \mathrm{~cm}$. All the measurements were taken using standard anthropometric points as described by Vallois [16].

The Shapiro-Wilk test was carried out to assess normality. As the proportion of normal distribution was low, sexual dimorphic differences were analyzed using the Mann-Whitney test $(\alpha=0.05)$, which was also used to compare populations. Pearson's correlation coefficients were used to assess the correlations between stature and each hand and foot measurement.

Stature is one of the three main biological profiling characteristics that can be estimated from the anthropometry of body parts. Since height correlates with hand and foot length in both study populations (see below), regression analyses were made in order to observe a) whether stature has a similar relationship with hand length in both sexes, and b) whether the degree of relationship between stature and the latter measurement is the same in both populations. In other words, only comparison between regressions (and not between correlations) can be used to assess whether one relationship is more significant than another. The left size was used for regression analysis. The degree of significance of the difference in slope and interception of the $Y$-axis between two lines of regression can be obtained with covariance analysis (ANCOVA), called the "univariate general linear model" in SPSS (version18). This software also allows comparisons of regressions from variance analysis (ANOVA), in which a dummy variable is binary-coded ( 0 or 1$)$ and another variable results from the product of the dummy variable and the independent variable accompanying covariates. The dummy variable serves to separate the two groups to be compared. To perform this analysis, a linear regression must be the starting point. In the resulting table, the dummy variable coefficient indicates the degree of significance of the difference intercepts with the $Y$-axis, while the coefficient of the product of this variable and the independent variable gives the comparison regression coefficients (slope) (Introduction to SAS. UCLA: Statistical Consulting Group; from http:// stats.idre.ucla.edu/sas/modules/; accessed November 22, 2018).

A paired $t$-test $(\alpha=0.05)$ was carried out to assess differences between real values for stature and the results obtained with the regression equations.

The relationship between stature (height) and body parts can also be investigated through allometric (scaling) analysis. Allometry is the study of the relationship of body size to

\begin{tabular}{|c|c|c|c|c|c|c|}
\hline Variable & Sex & Mean & SD & ES & Range & M-W \\
\hline \multirow[t]{2}{*}{ Age (years) } & Male & 27.1 & 6.83 & & $18.2-52.8$ & \\
\hline & Female & 24.6 & 5.85 & & $18.6-52.3$ & \\
\hline \multirow[t]{2}{*}{ Stature $(\mathrm{cm})$} & Male & 178.88 & 6.85 & 0.98 & $162-197$ & $*$ \\
\hline & Female & 162.60 & 5.08 & 0.72 & $153-172$ & \\
\hline \multirow{2}{*}{ Weight (kg) } & Male & 70.57 & 12.11 & 1.73 & $52-116$ & * \\
\hline & Female & 57.58 & 11.47 & 1.62 & $37-89$ & \\
\hline \multirow[t]{2}{*}{ Right hand length $(\mathrm{cm})$} & Male & 17.54 & 1.69 & 0.24 & $15-21.5$ & * \\
\hline & Female & 16.78 & 1.21 & 0.17 & $13-18.5$ & \\
\hline \multirow[t]{2}{*}{ Right hand width (cm) } & Male & 7.13 & 1.02 & 0.15 & $5.4-9$ & \\
\hline & Female & 7.03 & 0.47 & 0.07 & $5.5-8$ & \\
\hline \multirow{2}{*}{ Left hand length $(\mathrm{cm})$} & Male & 17.52 & 1.66 & 0.24 & $14.7-21$ & \\
\hline & Female & 16.83 & 1.19 & 0.17 & 13-19 & \\
\hline \multirow{2}{*}{ Left hand width $(\mathrm{cm})$} & Male & 7.06 & 1.02 & 0.15 & $5-9$ & \\
\hline & Female & 6.90 & 0.49 & 0.07 & $5-7.9$ & \\
\hline \multirow[t]{2}{*}{ Right foot length $(\mathrm{cm})$} & Male & 24.47 & 2.07 & 0.3 & $20-28.7$ & $*$ \\
\hline & Female & 22.68 & 1.47 & 0.21 & $18-25$ & \\
\hline \multirow[t]{2}{*}{ Right foot width $(\mathrm{cm})$} & Male & 7.71 & 1.49 & 0.21 & $5.5-12$ & \\
\hline & Female & 7.45 & 0.03 & 0.15 & $4.5-9$ & \\
\hline \multirow[t]{2}{*}{ Left foot length $(\mathrm{cm})$} & Male & 24.42 & 2.04 & 0.29 & $20.5-29$ & * \\
\hline & Female & 22.5 & 1.57 & 0.22 & $18-25.3$ & \\
\hline \multirow{2}{*}{ Left foot width $(\mathrm{cm})$} & Male & 7.50 & 1.33 & 0.19 & $5-10.2$ & \\
\hline & Female & 7.34 & 1.05 & 0.15 & $5-8.8$ & \\
\hline
\end{tabular}


shape, or in other words the relationship between changes in body size and changes in a ratio between body parts [17]. If changes in body size are not followed by modifications in the ratio between body parts, the process is called isometric, where the shape remains the same when size changes. On the other hand, if changes in body size produce changes in the ratio between body parts, this is referred to as allometric, where changes in body size are accompanied by changes in shape (body proportion). Thus, stature corresponds to the main trait and any change in size in a body part has to be related to it. In allometric analysis, stature is considered as the independent variable.

Allometry is best assessed by comparing ln-transformed data [18]. In our study, hand length (HL) and foot length (FL) were considered for the allometric analysis. We regressed $\ln$-stature with the ratio $\mathrm{ln}-\mathrm{HL}$ or $\mathrm{ln}-\mathrm{FL} / \mathrm{ln}$-stature. Least-square regressions were obtained by sex for Sudanese Arabs and Somalis. If the regression coefficient is significant, scaling of the traits is allometric; if regression coefficients are not significant, scaling is isometric. Changes in stature among adult individuals are expected to produce an isometric variation in $\mathrm{HL}$ and FL, in other words the ratio between these measurements and the stature should remain the same independently of changes in height. All statistical analyses were performed with SPSS (version 18).

\section{Results}

Sexual dimorphism is not expressed in the same way in the two populations. In Somalis, significant differences are observed in all measurements except weight, whereas in Sudanese Arabs, significant sexual dimorphism is recorded in height, weight, right hand length and foot length (Tables 1, 2). Comparisons between the populations suggest that there are no significant differences between males, but in females, significant differences are observed in weight, hand length as well as in foot length and width, with Sudanese Arabs showing higher values than Somalis except for weight.

Significant correlations were found between measurements of hands and feet in both populations $(P<0.01)$. In Sudanese Arabs, hand length and foot length were correlated with height. In Somalis, hand length was correlated with height in both males and females, whereas foot length was correlated with height only in females (Tables 3,4 ).

\section{Regression Coefficient}

The regression equations are presented in table 5. Although the correlations between height and hand length and foot length are significant, the coefficient of determination $\left(R^{2}\right)$

\begin{tabular}{|c|c|c|c|c|c|c|}
\hline Variable & Sex & Mean & SD & SE & Range & M-W \\
\hline \multirow[t]{2}{*}{ Age (years) } & Male & 22.6 & 2.42 & & $18.4-29$ & \\
\hline & Female & 24 & 5.65 & & $18.3-53.1$ & \\
\hline \multirow[t]{2}{*}{ Stature $(\mathrm{cm})$} & Male & 176.1 & 7.77 & 1.21 & 162-194 & * \\
\hline & Female & 162.93 & 5.00 & 0.95 & $155-173$ & \\
\hline \multirow{2}{*}{ Weight (kg) } & Male & 66.1 & 13.43 & 2.1 & $48-107$ & \\
\hline & Female & 64.82 & 14.62 & 2.76 & $42-92$ & \\
\hline \multirow[t]{2}{*}{ Right hand length $(\mathrm{cm})$} & Male & 17.32 & 1.59 & 0.25 & $13-20$ & $*$ \\
\hline & Female & 15.78 & 1.53 & 0.29 & $13-18.3$ & \\
\hline \multirow[t]{2}{*}{ Right hand width (cm) } & Male & 7.36 & 0.66 & 0.1 & $5.2-8.6$ & $*$ \\
\hline & Female & 6.86 & 0.5 & 0.09 & $5.3-7.8$ & \\
\hline \multirow[t]{2}{*}{ Left hand length $(\mathrm{cm})$} & Male & 17.49 & 1.46 & 0.23 & $13.8-20.5$ & $*$ \\
\hline & Female & 15.76 & 1.49 & 0.28 & $13.5-18.2$ & \\
\hline \multirow{2}{*}{ Left hand width $(\mathrm{cm})$} & Male & 7.36 & 0.65 & 0.1 & $5.4-8.6$ & * \\
\hline & Female & 6.71 & 0.51 & 0.1 & $5.3-7.8$ & \\
\hline \multirow[t]{2}{*}{ Right foot length $(\mathrm{cm})$} & Male & 24.05 & 2.04 & 0.32 & $19.7-28.3$ & $*$ \\
\hline & Female & 21.59 & 1.68 & 0.32 & $18.5-25$ & \\
\hline \multirow[t]{2}{*}{ Right foot width $(\mathrm{cm})$} & Male & 8.10 & 1.09 & 0.17 & $5.6-10.4$ & * \\
\hline & Female & 6.47 & 1.34 & 0.25 & $4.3-8.7$ & \\
\hline \multirow[t]{2}{*}{ Left foot length $(\mathrm{cm})$} & Male & 24.25 & 2.00 & 0.31 & $19.9-28.5$ & $*$ \\
\hline & Female & 21.53 & 1.61 & 0.3 & $18.5-24.8$ & \\
\hline \multirow{2}{*}{ Left foot width $(\mathrm{cm})$} & Male & 8.00 & 1.07 & 0.17 & $5.7-10$ & * \\
\hline & Female & 6.45 & 1.36 & 0.26 & $4.5-9$ & \\
\hline
\end{tabular}




\begin{tabular}{|c|c|c|c|c|c|c|c|c|c|c|c|}
\hline Variable & Sex & $\mathbf{S}$ & $\mathbf{W}$ & RHL & RHW & LHL & LHW & RFL & RFW & LFL & LFW \\
\hline \multirow[t]{2}{*}{ Stature } & Male & & 0.31 & 0.48 & -0.16 & 0.44 & -0.1 & 0.46 & 0.07 & 0.47 & 0.02 \\
\hline & Female & & 0.18 & 0.46 & 0.26 & 0.44 & 0.15 & 0.59 & 0.41 & 0.60 & 0.38 \\
\hline \multirow[t]{2}{*}{ Weight } & Male & $*$ & & 0.28 & 0.03 & 0.21 & -0.02 & 0.02 & -0.04 & 0.05 & -0.01 \\
\hline & Female & $\mathrm{ns}$ & & 0.28 & 0.29 & 0.28 & 0.24 & 0.13 & 0.32 & 0.14 & 0.32 \\
\hline \multirow[t]{2}{*}{ Right hand length } & Male & $* *$ & $*$ & & 0.50 & 0.97 & 0.44 & 0.75 & 0.58 & 0.77 & 0.68 \\
\hline & Female & $* *$ & $*$ & & 0.61 & 0.97 & 0.45 & 0.78 & 0.79 & 0.8 & 0.75 \\
\hline \multirow[t]{2}{*}{ Right hand width } & Male & ns & ns & $* *$ & & 0.50 & 0.94 & 0.48 & 0.58 & 0.47 & 0.66 \\
\hline & Female & $\mathrm{ns}$ & $*$ & $* *$ & & 0.63 & 0.87 & 0.34 & 0.50 & 0.37 & 0.54 \\
\hline \multirow[t]{2}{*}{ Left hand length } & Male & $* *$ & ns & $* *$ & $* *$ & & 0.43 & 0.73 & 0.58 & 0.76 & 0.70 \\
\hline & Female & $* *$ & ns & $* *$ & $* *$ & & 0.45 & 0.77 & 0.79 & 0.79 & 0.76 \\
\hline \multirow[t]{2}{*}{ Left hand width } & Male & ns & ns & $* *$ & $* *$ & $* *$ & & 0.44 & 0.51 & 0.44 & 0.56 \\
\hline & Female & ns & ns & $* *$ & $* *$ & $* *$ & & 0.24 & 0.43 & 0.27 & 0.46 \\
\hline \multirow[t]{2}{*}{ Right foot length } & Male & $* *$ & ns & $* *$ & $* *$ & $* *$ & $* *$ & & 0.55 & 0.98 & 0.65 \\
\hline & Female & $* *$ & ns & $* *$ & $* *$ & $* *$ & & & 0.74 & 0.98 & 0.68 \\
\hline \multirow[t]{2}{*}{ Right foot width } & Male & $* *$ & ns & $* *$ & $* *$ & $* *$ & $* *$ & $* *$ & & 0.56 & 0.83 \\
\hline & Female & $* *$ & $*$ & $* *$ & $* *$ & $* *$ & $* *$ & $* *$ & & 0.79 & 0.94 \\
\hline \multirow[t]{2}{*}{ Left foot length } & Male & $* *$ & ns & $* *$ & $* *$ & $* *$ & $* *$ & $* *$ & $* *$ & & 0.66 \\
\hline & Female & $* *$ & ns & $* *$ & $* *$ & $* *$ & ns & $* *$ & $* *$ & & 0.75 \\
\hline \multirow[t]{2}{*}{ Left foot width } & Male & $* *$ & ns & $* *$ & $* *$ & $* *$ & $* *$ & $* *$ & $* *$ & $* *$ & \\
\hline & Female & $* *$ & $*$ & $* *$ & $* *$ & $* *$ & $* *$ & $* *$ & $* *$ & $* *$ & \\
\hline \multicolumn{12}{|c|}{ 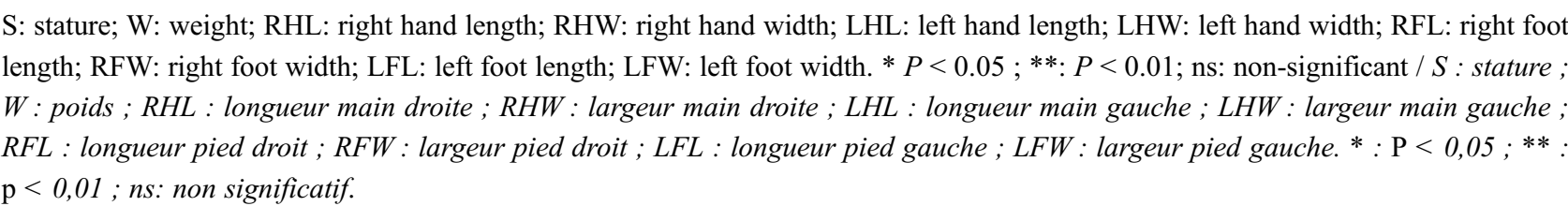 } \\
\hline
\end{tabular}

is low. This means that only a small proportion of the observed variation in stature can be estimated by hand or foot length. Around $20 \%$ of the stature can be predicted from hand length in all the Sudanese Arabs and male Somalis and around 30\% from hand length and foot length in female Somalis.

Comparisons among the regressions show that they do not differ between the sexes or between Sudanese Arabs and Somalis (Table 5, Figs 1, 2). In other words, the relationship between stature and hand length and foot length is similar in both sexes and in both populations. The regression equations were therefore obtained for the sexes pooled together (Table 5). A paired $t$-test showed no significant differences between the real values for stature and the results obtained with the regression equations (Table 6).

\section{Allometry}

Almost all the regressions are non-significant, suggesting that changes in height are not accompanied by any change in proportion and that the relationship is therefore isometric (Fig. 3). There are two significant regressions, one between stature and the foot length/height ratio in female Sudanese Arabs and the other between stature and the hand length/ height ratio in female Somalis, which suggests an allometric relationship. However, detailed analysis of the data revealed that these two significant regressions are the product of a few extreme values in a small sample size (type I error); both regressions have a low coefficient of determination $\left(R^{2}<\right.$ 0.2 ). Furthermore, the comparison of regressions for hand and foot measurements between sexes and populations fail to show any significant differences between them. Therefore, changes in size and shape follow the same scaling, so that the relationship is isometric.

\section{Discussion and conclusions}

The expansion of forensic studies in recent years has greatly increased the production of studies on anthropometry linked to the identification of the sex, age, stature and ancestry of individuals. In particular, hand and foot dimensions have been widely tested for use as proxies for stature in many different populations (see Asadujjaman et al. [19] for a 


\begin{tabular}{|c|c|c|c|c|c|c|c|c|c|c|c|}
\hline Variable & $\operatorname{Sex}$ & $\mathbf{S}$ & $\mathbf{W}$ & RHL & RHW & LHL & LHW & RFL & RFW & LFL & LFW \\
\hline \multirow[t]{2}{*}{ Stature } & Male & & 0.46 & 0.48 & 0.22 & 0.43 & 0.29 & 0.24 & 0.22 & 0.29 & 0.26 \\
\hline & Female & & 0.36 & 0.43 & 0.15 & 0.52 & 0.28 & 0.59 & 0.37 & 0.57 & 0.49 \\
\hline \multirow[t]{2}{*}{ Weight } & Male & $* *$ & & 0.34 & 0.39 & 0.36 & 0.45 & 0.55 & 0.59 & 0.52 & 0.55 \\
\hline & Female & ns & & 0.34 & 0.19 & 0.34 & 0.45 & 0.32 & 0.21 & 0.35 & 0.34 \\
\hline \multirow[t]{2}{*}{ Right hand length } & Male & $* *$ & $*$ & & 0.44 & 0.90 & 0.44 & 0.53 & 0.51 & 0.67 & 0.54 \\
\hline & Female & $* *$ & $*$ & & 0.38 & 0.93 & 0.34 & 0.57 & 0.46 & 0.57 & 0.49 \\
\hline \multirow[t]{2}{*}{ Right hand width } & Male & ns & $*$ & $* *$ & & 0.49 & 0.92 & 0.35 & 0.57 & 0.53 & 0.57 \\
\hline & Female & ns & ns & $* *$ & & 0.34 & 0.84 & 0.31 & 0.56 & 0.34 & 0.55 \\
\hline \multirow[t]{2}{*}{ Left hand length } & Male & $* *$ & $*$ & $* *$ & $* *$ & & 0.54 & 0.54 & 0.57 & 0.71 & 0.62 \\
\hline & Female & $* *$ & $*$ & $* *$ & $* *$ & & 0.32 & 0.66 & 0.4 & 0.65 & 0.41 \\
\hline \multirow[t]{2}{*}{ Left hand width } & Male & ns & $* *$ & $* *$ & $* *$ & $* *$ & & 0.32 & 0.59 & 0.50 & 0.91 \\
\hline & Female & * & $*$ & $* *$ & $* *$ & $* *$ & & 0.34 & 0.5 & 0.36 & 0.47 \\
\hline \multirow[t]{2}{*}{ Right foot length } & Male & ns & $* *$ & $* *$ & $*$ & $* *$ & $*$ & & 0.69 & 0.84 & 0.61 \\
\hline & Female & $* *$ & $* *$ & $* *$ & $*$ & $* *$ & $* *$ & & 0.49 & 0.94 & 0.39 \\
\hline \multirow[t]{2}{*}{ Right foot width } & Male & ns & $* *$ & $* *$ & $* *$ & $* *$ & $* *$ & $* *$ & & 0.74 & 0.95 \\
\hline & Female & ns & $*$ & $* *$ & $* *$ & $* *$ & $* *$ & $* *$ & & 0.46 & 0.85 \\
\hline \multirow[t]{2}{*}{ Left foot length } & Male & ns & $* *$ & $* *$ & $* *$ & $* *$ & $* *$ & $* *$ & $* *$ & & 0.69 \\
\hline & Female & $* *$ & $* *$ & $* *$ & $*$ & $* *$ & $* *$ & $* *$ & $* *$ & & 0.41 \\
\hline \multirow[t]{2}{*}{ Left foot width } & Male & ns & $* *$ & $* *$ & $* *$ & $* *$ & $* *$ & $* *$ & $* *$ & \multirow{2}{*}{\multicolumn{2}{|c|}{$* *$}} \\
\hline & Female & * & $*$ & $* *$ & $*$ & $* *$ & $* *$ & $* *$ & $* *$ & & \\
\hline
\end{tabular}

review on hand dimensions [e.g. 20-23]). Hand length and foot length are described as presenting the highest coefficients of correlation and determination. Of these two measurements, foot length has the highest coefficient of determination in linear regressions but it is never higher than 0.590 [24]. At present, it is not possible to draw any general inferences from the body of works on forensic anthropology about the relationship between stature and hand and foot length, since the determination coefficients sometimes differ widely between sexes for the same population or even between right and left sizes in the same sample of individuals [e.g. 13,24]. Furthermore, the majority of forensic studies are focused on a single population, and although some authors compare their results with previous works, raw data from different populations are rarely available. Studies covering more than one population therefore have limited possibilities for comparisons of average values and for inferring a higher or lower coefficient of correlation (see below). In other words, few studies have addressed comparisons of the pattern of relationships between stature and hand or foot length among different populations.
In the first published data on Sudanese Arabs, Ahmed [12-14] showed the potential of hand and foot measurements from Sudan to estimate stature. No data exist from Somalia. Our results, as indicated above, are based on the measurements taken only once and by one observer, so that intra and inter-observer variability have not been assessed (see Methods). However, for stature and hand and foot length, they are very close to those previously reported. We confirm that length measurements produce higher correlations with stature than width measurements and are therefore more suited to estimations of adult height in both groups, Sudanese Arabs and Somalis. However, the coefficient of determination is low, implying limited potential usefulness of regression equations to determine stature from hand or foot length. Figures 1, 2 show the dispersion of hand and foot length measurements for stature. Ahmed $[12,13]$ reports higher coefficients of determination but the paired $t$-tests do not appear to be more accurate: in fact the paired $t$-test in our study shows an extremely small average difference when real values are compared to calculated values. This suggests that the equations presented in table 5 , although limited in 
Table 5 Comparisons between regression coefficients / Comparaison entre les coefficients de régression

\begin{tabular}{|c|c|c|c|c|c|c|c|c|}
\hline & Features & Sex & Regression equation & $\mathbf{R}^{2}$ & SEE & IC95\% & $P$ & Sign \\
\hline \multirow[t]{6}{*}{ Sudanese Arabs } & S - LHL & Male & $\mathrm{S}=147.257+1.804 \mathrm{LHL}$ & 0.191 & & & 0.927 & ns \\
\hline & & Female & $\mathrm{S}=130.977+1.879 \mathrm{LHL}$ & 0.194 & & & & \\
\hline & & F-M & $\mathrm{S}=118.619+3.03 \mathrm{LHL}$ & 0.195 & 0.625 & 1.241 & & \\
\hline & $\mathrm{S}-\mathrm{LFL}$ & Male & $\mathrm{S}=140.303+1.58 \mathrm{LFL}$ & 0.220 & & & 0.529 & ns \\
\hline & & Female & $\mathrm{S}=118.525+1.959 \mathrm{LFL}$ & 0.364 & & & & \\
\hline & & F-M & $\mathrm{S}=95.025+3.225 \mathrm{LFL}$ & 0.423 & 0.382 & 0.758 & & \\
\hline \multirow[t]{6}{*}{ Somalis } & S - LHL & Male & $\mathrm{S}=135.929+2.297 \mathrm{LHL}$ & 0.185 & & & 0.696 & ns \\
\hline & & Female & $\mathrm{S}=133.133+1.891 \mathrm{LHL}$ & 0.315 & & & & \\
\hline & & F-M & $\mathrm{S}=111.435+3.534 \mathrm{LHL}$ & 0.406 & 0.522 & 1.042 & & \\
\hline & $\mathrm{S}-\mathrm{LFL}$ & Male & $\mathrm{S}=148.777+1.127 \mathrm{LFL}$ & 0.084 & & & 0.478 & ns \\
\hline & & Female & $\mathrm{S}=124.566+1.782 \mathrm{LFL}$ & 0.329 & & & & \\
\hline & & F-M & $\mathrm{S}=111.708+2.551 \mathrm{LFL}$ & 0.385 & 0.394 & 0.786 & & \\
\hline Sudanese Arabs & S - LHL & Male & $\mathrm{S}=147.257+1.804 \mathrm{LHL}$ & & & & 0.595 & ns \\
\hline Somalis & S - LHL & Male & $\mathrm{S}=135.929+2.297 \mathrm{LHL}$ & & & & & \\
\hline Sudanese & S - LHL & Female & $\mathrm{S}=130.977+1.879 \mathrm{LHL}$ & & & & 0.988 & ns \\
\hline \multicolumn{9}{|l|}{ Arabs } \\
\hline Somalis & S - LHL & Female & $\mathrm{S}=133.133+1.891 \mathrm{LHL}$ & & & & & \\
\hline Sudanese & $\mathrm{S}-\mathrm{LFL}$ & Male & $\mathrm{S}=140.303+1.58 \mathrm{LFL}$ & & & & 0.532 & ns \\
\hline \multicolumn{9}{|l|}{ Arabs } \\
\hline Somalis & $\mathrm{S}-\mathrm{LFL}$ & Male & $\mathrm{S}=148.777+1.127 \mathrm{LFL}$ & & & & & \\
\hline Sudanese & $\mathrm{S}-\mathrm{LFL}$ & Female & $\mathrm{S}=118.525+1.959 \mathrm{LFL}$ & & & & 0.776 & ns \\
\hline \multicolumn{9}{|l|}{ Arabs } \\
\hline Somalis & $\mathrm{S}-\mathrm{LFL}$ & Female & $\mathrm{S}=124.566+1.782 \mathrm{LFL}$ & & & & & \\
\hline
\end{tabular}

Table 6 Paired $t$-test between real stature and stature estimated from regression equation / $\mathrm{t}$-test apparié entre la stature et la stature estimée avec les équations de régression

\begin{tabular}{|lllllll}
\hline & Features & Dif. Average & Correlation & Sign & Sig. $\boldsymbol{t}$-test \\
\hline Sudanese Arabs & S - LFL & 0.00369 & 0.651 & $P<0.001$ & 0.996 \\
Somalis & S - LFL & 0.00291 & 0.62 & $P<0.001$ & 0.997 \\
Sudanese Arabs & S - LHL & 0.00498 & 0.441 & $P<0.001$ & 0.996 \\
Somali & S - LHL & 0.00136 & 0.637 & $P<0.001$ & 0.999 \\
\hline
\end{tabular}

S: stature; LFL: left foot length; LHL: left hand length / S : stature ; LFL : longueur pied gauche ; LHL : longueur main gauche

their power to produce a stature estimation for individuals, can be used at the population level.

Our results also confirm that all measurements for Sudanese Arabs are highly correlated [14]. The strong correlation between upper and lower limb dimensions has also been observed in many other populations [e.g. 24-26]. Comparisons of regression coefficients show that those for hands and feet are similar irrespective of sex. This probably suggests that the dimensions of limb parts are highly integrated genetically and that establishing a single regression equation for each population would enable the size of different parts to be estimated, as stature maintains similar relationships with hands and feet independently of sex.

Sexual dimorphism was observed in almost all metric dimensions in the Somalis but in the Sudanese Arabs it was only present in height, weight and foot length. Sexual dimorphism does not contradict the suggestion that stature maintains the same relationship with other body parts in both 
Sudanese Arabs

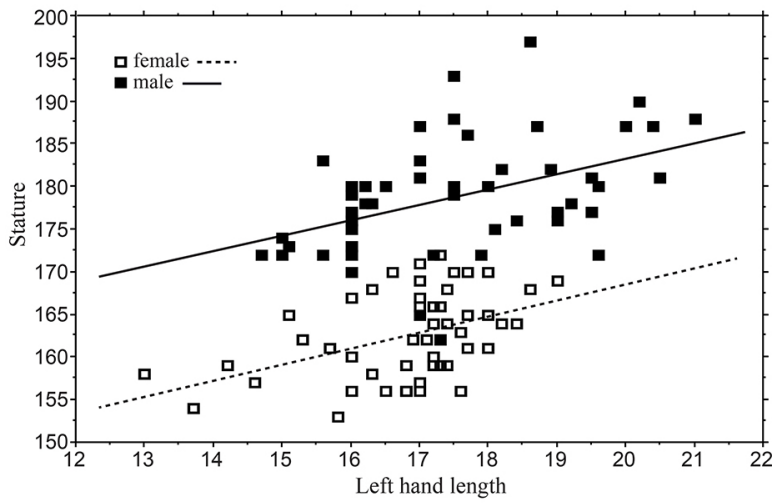

Somali

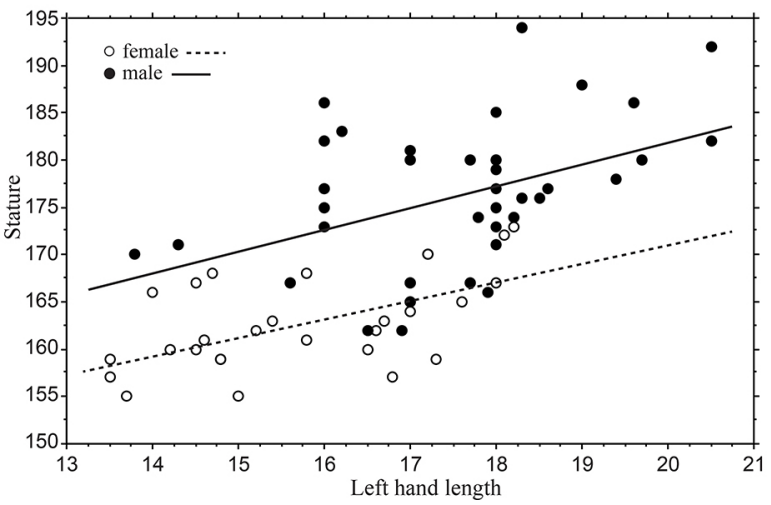

Fig. 1 Linear regressions between stature and left hand length in each population. Regressions do not differ between sexes in each population. Measurements in $\mathrm{cm} /$ Régression linéaire entre la stature et la longueur de la main gauche dans chaque population. Les régressions ne sont pas différentes entre les sexes dans chaque population. Mesures en $\mathrm{cm}$.

sexes (isometry). Sexual differences along the same isometric scale have already been described for other traits in humans [e.g. 27,28]. Similar coefficients of regression for hand and foot length in both sexes in both populations suggest that sexual differences in dimensions are expressed along the same scale.

In some populations, stature, body part dimensions and/ or body proportions are highly distinctive [7,29], which suggests that the relationships between stature and body parts expressed through correlation/regression coefficients is population-specific [30-32]. This is not the case between Sudanese Arabs and Somalis: the analysis of regression coefficients carried out in the present study suggests that the relationship between stature and hand and foot length is same in these two populations. It is worth emphasizing the importance of this analysis because some authors have advanced an interpretation of their results based only on the different raw values of the correlation coefficients without conducting any tests to assess the significance of the differences. Some studies even interpret differences between
Females

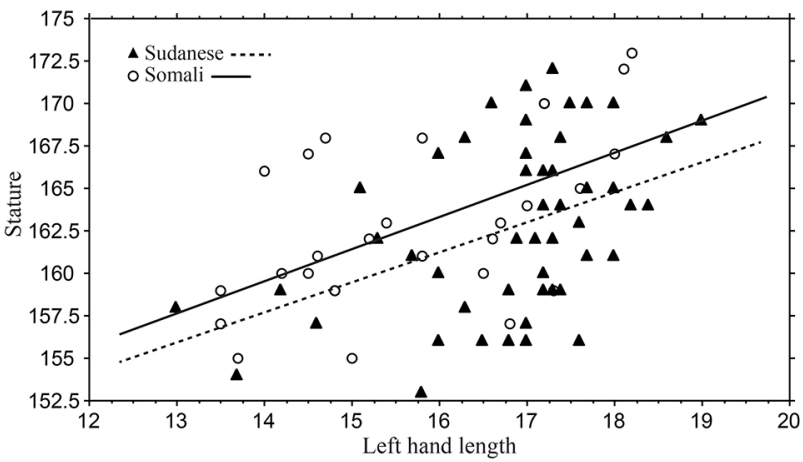

Males

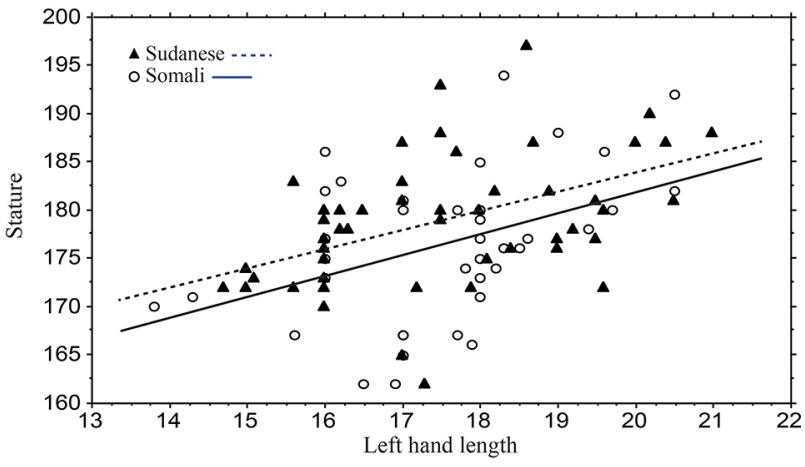

Fig. 2 Linear regressions between stature and left hand length by sex. The regression between populations do not differ and the relationship between stature and hand length is similar in the two populations. Measurements in $\mathrm{cm} /$ Régression linéaire entre la stature et la longueur de la main gauche par sexe. Les régressions ne sont pas différentes entre les populations, la relation entre la stature et la longueur de la main est similaire chez les deux populations. Mesures en $\mathrm{cm}$.

correlation coefficients as differences between populations [e.g. 15,33], so that a higher correlation coefficient is incorrectly interpreted as an indication of a more important relationship [e.g. 23]. Whether differences exist cannot be assessed from the raw values of coefficients: any comparison between coefficients has to be done following a statistical method (ANCOVA or the one used in this study). In other words, previous studies based only on correlation coefficients cannot determine whether differences exist among populations, so that the use of different correlations to estimate stature from body parts is not warranted at present.

Allometric analysis shows that both populations follow a variation in hand and foot length that expresses changes in height isometrically. This indicates that changes in stature are accompanied by proportional changes in hand and foot dimensions [e.g. 34,35].

Few studies have investigated genetic diversity in East Africa. In Sudan, the four main African language families are present, which suggests a complex history of migration 


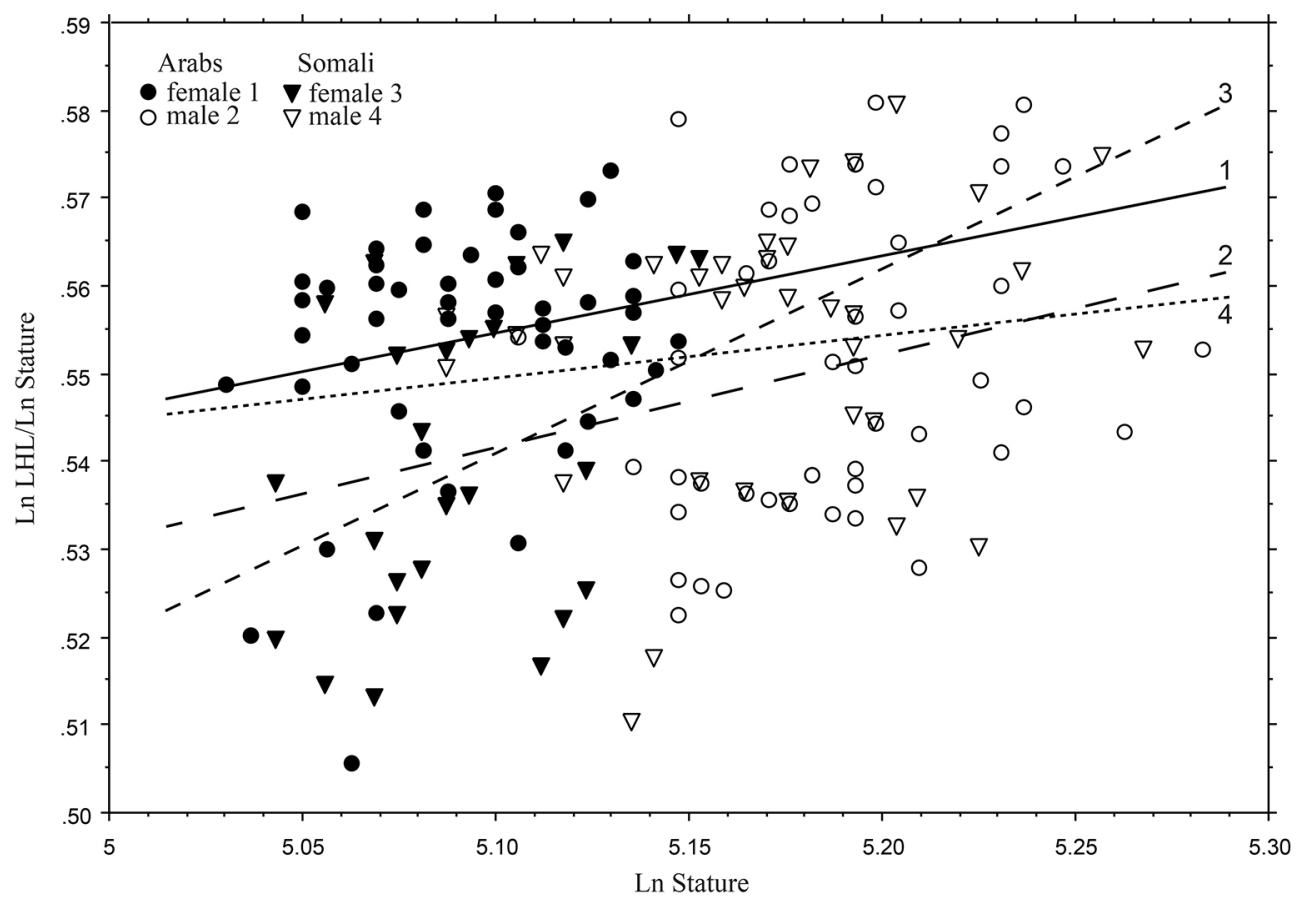

Fig. 3 Allometric relationships between stature and left hand length. The regressions are not significant, thus suggesting an isometric relationship between these two characteristics. In female Somalis, the regression is significant at $\alpha=0.05$, but is due to two extreme values: further comparison between regressions fails to reveal any difference among them, suggesting that all relationships follow an isometric scaling / Relation allométrique entre la stature et la longueur de la main gauche. Les régressions ne sont pas significatives, ce qui suggère un rapport isométrique entre ces deux caractéristiques. Chez les femmes somalies, la régression est significative à $\alpha=0,05$, mais cela est dû aux deux valeurs extrêmes ; la comparaison entre les régressions ne révèle aucune différence entre elles, ce qui suggère que toutes les relations suivent un rapport isométrique.

and admixture. Babiker et al. [36] have analyzed 15 microsatellites in several ethnic groups from Sudan, and compared them to published results from neighbouring populations including Somalis. They reported the Somali people as the most genetically distinct from other northeast African groups. Dobon et al. [37] observed that Sudanese Arabs and Ethiopians share the same polymorphisms and are clearly distinct from other groups. This study was based on an analysis of 200,000 single-nucleotide polymorphisms from the region. A language link also exists, as Sudanese Arabs and Ethiopians speak languages that are included in the Afro-Asiatic family. A genetic study of the Y chromosome in the region has revealed a strong correlation between genetic and linguistic structure [38]. Since Somalis also speak a language that belongs to the Afro-Asiatic family, the strong link between genetic and linguistic traits could predict a close affinity between Somalis and Sudanese Arabs. Like the genetic studies, our study on body measurements also point to a close affinity between these two populations.

To summarize, hand and foot lengths can be used in estimations of the stature of individuals of Sudanese Arab and Somali origin, but any prediction requires caution because of the low values of the coefficient of determination. The regressions expressing the relationship between stature and hand and foot lengths are similar in both populations and sexes, suggesting a close affinity among these groups. The identification of sex and differentiation of one population from the other is not possible using hand and foot anthropometry alone.

Conflict of interest: The authors declare that they have no conflicts of interest. This research did not receive any specific grant from funding agencies in the public, commercial or not-for-profit sectors.

\section{References}

1. Deniker J (1908) La taille en Europe. BMSAP série V 9:456-62

2. Czekanowski J (1922) Forschungen im Nil-Kongo-Zwischengebeit. Anthropologische Beobachtungen. Wissenschaftliche ergebnisse der Deutschen Zentral-Afrika-Expedition 1907-1908. Ethnographie-Anthropologie IV. Klinkhardt and Biermann, Leipzig, pp 143-473

3. Hiernaux J (1968) La diversité humaine en Afriques subsaharienne. Recherches biologiques. Institut de sociologie de l'Université Libre de Bruxelles, Bruxelles, 262 p 
4. Eveleth PB, Tanner JM (1990) Worldwide variation in human growth, 2nd edn. Cambridge University Press, Cambridge, $497 \mathrm{p}$

5. Stulp G, Barrett L (2014) Evolutionary perspectives on human height variation. Biol Rev 91:206-34

6. Hiernaux J, Froment A (1976) The correlations between anthropo-biological and climatic variables in sub-Saharan Africa: revised estimates. Hum Biol 48:757-67

7. Ramirez Rozzi FV, Koudou Y, Froment A, et al (2015) Growth pattern from birth to adulthood in African pygmies of known age. Nat Commun 6:7672

8. Schebesta P (1938) Die Bambuti-Pygmaen vom Ituri. I.-Geschichte, Geographie, Unwelt, Demographie und Anthropologie der Ituri-Bambuti, belgisch Congo. G. van Campenhout, Bruxelles, $438 \mathrm{p}$

9. Pagezy H (1978) Morphological, physical and ethoecological adaptations of Oto and Twa women living in the equatorial forest (Tumba Lake, Zaire). J Hum Evol 7:683-92

10. Becker NS, Verdu P, Froment A, et al (2011) Indirect evidence for the genetic determination of short stature in African pygmies. Am J Phys Anthropol 145:390-401

11. Ruff CB (1994) Morphological adaptation to climate in modern and fossil hominids. Yearb Phys Anthropol 37:65-108

12. Ahmed AA (2013) Estimation of stature from the upper limb measurements of Sudanese adults. Forensic Sci Int 228:e1-e7

13. Ahmed AA (2013) Estimation of stature using lower limb measurements in Sudanese Arabs. J Forensic Leg Med 20:483-8

14. Ahmed AA (2014) A study of the anthropometric correlations between upper limb measurements for personal identification in Sudanese population. Homo 65:489-98

15. Ahmed AA, Taha S (2016) Cephalo-facial analysis to estimate stature in a Sudanese population. Leg Med (Tokyo) 20:80-6

16. Vallois HV (1965). Anthropometric techniques. Curr Anthropol 6:127-44

17. Gould SJ (1977) Ontogeny and phylogeny. Belknap Press of Harvard University Press, Cambridge, $501 \mathrm{p}$

18. Gingerich PD, Smith BH, Rosenberg K (1982) Allometric scaling in the dentition of primates and prediction of body weight from tooth size in fossils. Am J Phys Anthropol 58:81-100

19. Asadujjaman M, Babor Ali Molla M, Nahid Al Noman S (2019) Stature estimation from hand anthropometric measurements in Bangladeshi population. J Forensic Leg Med 65:86-91

20. Saxena SQ (1984) A study of correlations and estimation of stature from hand length, hand breadth and sole length. Anthropol Anz 42:271-76

21. Sanli SG, Kizilkanat ED, Boyan N, et al (2005) Stature estimation based on hand length and foot length. Clin Anat 18:589-96

22. Zeybek G, Ergur I, Demiroglu Z (2008) Stature and gender estimation using foot measurements. Forensic Sci Int 181:54e1-54e5
23. Uhrová $\mathrm{P}$, Beňuš R, Masnicová $\mathrm{S}$, et al (2015) Estimation of stature using hand and foot dimensions in Slovak adults. Leg Med 17:92-97

24. Kanchan T, Menezes RG, Moudgil R, et al (2010) Stature estimation from foot length using universal regression formula in a North Indian population. J Forensic Sci 55:163-6

25. Krishan K, Sharma A (2007) Estimation of stature from dimensions of hands and feet in a North Indian population. J Forensic Leg Med 14:327-32

26. Ozaslan A, Koc S, Ozaslan I, et al (2006) Estimation of stature from upper extremity. Mil Med 171:288-91

27. Velemínská J, Bigoni L, Krajíček V, et al (2012) Surface facial modelling and allometry in relation to sexual dimorphism. Homo 63:81-93

28. Fischer B, Mitteroecker P (2017) Allometry and sexual dimorphism in the human pelvis. Anat Rec 300:698-705

29. Ruff CB, Niskanen M, Junno JA, et al (2005) Body mass prediction from stature and bi-iliac breadth in two high latitude populations, with application to earlier higher latitude humans. J Hum Evol 48:381-92

30. Krishan K, Kanchan T, Sharma A (2012) Multiplication factor versus regression analysis in stature estimation from hand and foot dimensions. J Forensic Leg Med 19:211-4

31. Rastogi P, Nagesh KR, Yoganarasimha K (2008) Estimation of stature from hand dimensions of north and south Indians. Leg Med (Tokyo) 10:185-9

32. Hasegawa I, Uenishi K, Fukunaga T, et al (2009) Stature estimation formulae from radiographically determined limb bone length in a modern Japanese population. Leg Med (Tokyo) 11:260-6

33. Akhlaghi M, Hajibeygi M, Zamani N, et al (2012) Estimation of stature from upper limb anthropometry in Iranian population. $\mathrm{J}$ Forensic Leg Med 19:280-4

34. Cheverud JM (1982) Relationships among ontogenetic, static, and evolutionary allometry. Am J Phys Anthropol 59:139-49

35. Pélabon C, Bolstad GH, Egset CK, et al (2013) On the relationship between ontogenetic and static allometry. Am Nat 181:195-212

36. Babiker HMA, Schlebusch C, Hassan HY, et al (2011) Genetic variation and population structure of Sudanese populations as indicated by 15 Identifiler sequence-tagged repeat (STR) loci. Investig Genet 2:12

37. Dobon B, Hassan HY, Laayouni H, et al (2015) The genetics of East African populations: a Nilo-Saharan component in the African genetic landscape. Sci Rep 5:9996

38. Hassan HY, Underhill PA, Cavalli-Sforza LL, et al (2008) Ychromosome variation among Sudanese: restricted gene flow, concordance with language, geography, and history. Am J Phys Anthropol 137:316-33 